\title{
KONSISTENSI PUTUSAN HAKIM TERHADAP PERKARA KERUGIAN LINGKUNGAN HIDUP DI INDONESIA
}

\author{
Sri Wahyuni ${ }^{1}$, Arum Nur Rahmawati ${ }^{2}$, Cheryl Permata K.D ${ }^{3}$, Widya Chrisna \\ Manika $^{4}$, Sapto Hermawan ${ }^{5}$ \\ 1, 2, 3, 4,5 Fakultas Hukum Universitas Sebelas Maret, Indonesia \\ *Correspondence: swyuni@staff.uns.ac.id
}

Received: 14 Juni 2021, Accepted: 23 September 2021, Published: 30 September 2021

\begin{abstract}
To ensure enviromental sustainability, environmental management must be supported by the enforcement of environmental law through litigation process, whether on criminal, civil, or administrative aspect. (In Indonesia, there are numerous cases of environmental losses, as well as examples of environmental damage that have been attempted on the court of mandalawangi, natural kallista and sungailiat cases.) The purpose of this research is to find out the extent of court decisions's concistencies on environmental cases Using normative legal research method, this research examined three court decisions form two different types of court, which are criminal court (Sungai Liat case) and civil court (Mandalawangi case and Kalistas case). It was found that these judicial decisions show inconsistencies. This condition may weaken the enforcement of environmental law in Indonesia. On the other hand, this difference in judgments may be apprehended as a new standpoint of environmental law in Indonesia.
\end{abstract}

Keywords: environmental damages; judgement consistency; environmental sentence.

\begin{abstract}
Abstrak
Keberlangsungan pengelolaan lingkungan hidup harus ditunjang dengan penegakan hukum lingkungan, baik melalui jalur peradilan maupun luar peradilan, baik yang bersifat perdata, pidana, maupun administrasi. Penelitian ini mengkaji tiga kasus lingkungan hidup yang diselesaikan melalui peradilan pidana dan perdata, yaitu Kasus Mandalawangi, Kasus Kallista Alam dan Kasus Sungailiat. Tujuan penelitian ini adalah untuk mengetahui problematika penegakan hukum lingkungan hidup di Indonesia, dan untuk mengetahui dampak dari konsistensi putusan hakim dalam perkara lingkungan di Indonesia yang berbeda-beda. Untuk mencapai tujuan tersebut, ketiga putusan hakim tersebut di atas dikaji dengan menggunakan metode penelitian hukum normatif. Hasil penelitian menunjukkan bahwa ketiga kasus tersebut diputuskan secara berbeda. Inkonsistensi tersebut dapat menjadi faktor pelemahan penegakan hukum lingkungan di Indonesia. Namun di samping itu dapat dimaknai sebagai suatu pandangan baru terhadap ketentuan lingkungan hidup di Indonesia.
\end{abstract}


Kata-kata Kunci: kerugian lingkungan hidup; konsistensi putusan hakim; putusan perkara lingkungan hidup.

\section{Pendahuluan}

Perlindungan dan pengelolaan lingkungan hidup merupakan upaya sistematis dan terpadu yang dilakukan untuk melestarikan fungsi lingkungan hidup dan mencegah terjadinya pencemaran dan/atau kerusakan lingkungan hidup yang meliputi perencanaan, pemanfaatan, pengendalian, pemeliharaan, pengawasan, dan penegakan hukum. ${ }^{1}$ Dalam sistem kenegaraan, Pemerintah Indonesia memiliki peran penting dalam melaksanakan perlindungan dan pengelolaan lingkungan hidup, memiliki kewenangan dalam membuat norma hukum dan peraturan mengenai pengelolaan lingkungan hidup di Indonesia, yang diharapkan dapat menyelaraskan, menyerasikan, dan menyeimbangkan antara kehidupan manusia dan lingkungannya. Namun seiring dengan berjalannya waktu, pemanfaatan lingkungan hidup menimbulkan berbagai masalah. Manusia menjadi pihak yang memiliki andil besar dalam kerusakan lingkungan. Manusia yang terus berkembang serta didukung oleh ilmu pengetahuan dan teknologi sering melakukan pembangunan tanpa memperhatikan aspek keseimbangan lingkungan dan lebih mementingkan aspek ekonomi, yang mana dapat menimbulkan kerusakan dan pencemaran lingkungan hidup. ${ }^{2}$

Pada dasarnya hakekat suatu lingkungan hidup adalah kehidupan yang melingkupi tata dan nilai-nilai kehidupan di dalamnya. Dalam hal ini mencakup tata dan nilai untuk menjaga keberlanjutan lingkungan hidup, sumber daya alam dan keadilan sosial bagi kehidupan manusia atas hak atas lingkungan yang sehat. Lingkungan hidup harus dipandang dan diperlakukan sebagai subyek, dikelola untuk kehidupan berkelanjutan bukan hanya untuk pertumbuhan pembangunan. ${ }^{3}$ Penyimpangan dalam pengelolaan lingkungan hidup ini dapat terjadi akibat lemahnya pengawasan terhadap pengelolaan lingkungan sehingga menimbulkan kerusakan lingkungan. Kerusakan lingkungan hidup dapat mengakibatkan perubahan sifat-sifat dan unsur-unsur dari lingkungan yang berakibat pada peran dan arti penting lingkungan hidup bagi kehidupan menjadi terganggu, bahkan tidak berfungsi lagi dan akan menimbulkan kerusakan lingkungan hidup. ${ }^{4}$

1 "Pasal 1 Angka 2 Undang-Undang Republik Indonesia Nomor 32 Tahun 2009 Tentang Perlindungan Dan Pengelolaan Lingkungan Hidup” (2009).

2 Sapto Hermawan and Wida Astuti, "Penggunaan Penta Helix Model Sebagai Upaya Integratif Memerangi Sampah Plasik Di Laut Indonesia," Bina Hukum Lingkungan 5, no. 2 (2021): 23761, https://doi.org/10.24970/bhl.v5i2.164.

3 Muhammad Amin Hamid, "Penegakan Hukum Pidana Lingkungan Hidup Dalam Menanggulangi Kerugian Negara," Legal Pluralism: Journal of Law Science 6, no. 1 (2016): 88-117.

4 Sutiyanti Juanda, "Representasi Kerusakan Lingkungan Di Indonesia Dalam Puisi Media Daring Indonesia (Kajian Ekokritik)," 3, no. 2 (2016): 98-107. 
Kerugian lingkungan hidup merupakan kerugian yang timbul akibat pencemaran atau perbuatan perusakan lingkungan sekitar yang dilakukan yang berkaitan dengan hak milik publik sehingga mengganggu kelangsungan hidup makhluk hidup di sekitarnya. Jika dilihat saat ini, kondisi lingkungan hidup sungguh sangat memprihatinkan, bahkan telah membahayakan hidup serta kehidupan makhluk hidup untuk generasi masa sekarang dan yang akan datang. Terkait dengan berbagai kasus mengenai kerugian lingkungan yang terjadi maka perlu menjamin kepastian hukum lingkungan sebagai upaya penegakan hukum guna menanggulangi permasalahan lingkungan hidup, hal ini dapat dilakukan melalui pengawasan dan penerapan secara administrasi, keperdataan, dan kepidanaan agar dapat menimbulkan kepatuhan terhadap ketentuan dan peraturan yang berlaku.

Aturan perundang-undangan secara menyeluruh digunakan sebagai penunjang penegakan hukum, dan sangat terikat dengan kualitas penegak hukum. Undang-Undang Nomor 32 Tahun 2009 tentang Perlindungan dan Pengelolaan Lingkungan Hidup menjelaskan terdapat 3 (tiga) cara sistematis dalam penegakan hukum, yaitu dapat dilakukan penegakan hukum secara administratif, melalui pengadilan dan penyidikan atas tindak pidana yang dikhususkan dalam lingkup lingkungan hidup atau penyelesaian suatu kasus atau sengketa di luar pengadilan. ${ }^{5}$ Namun penegakannya masih menghadapi problematika, sehingga membutuhkan perhatian lebih demi menjaga keadaan lingkungan yang merupakan sumber utama keberlangsungan hidup manusia. Jika usaha yang dilakukan di luar pengadilan tidak berhasil maka dapat dilakukan dengan jalur pengadilan. Penyelesaian konflik di pengadilan memerlukan konsistensi putusan hakim, karena inkonsistensi putusan dapat menjadi suatu alasan melemahnya penegakan hukum lingkungan di Indonesia.

Beberapa literatur telah membahas mengenai putusan pengadilan kasus lingkungan, di antaranya yaitu artikel yang ditulis oleh Anindita, mengupas tentang besaran ganti kerugian untuk perkara lingkungan yang lebih adil dan proporsional. Dalam kesimpulan artikel tersebut, penulis mendorong kuat dibentuknya peradilan khusus yang membahas isu lingkungan hidup. ${ }^{6}$ Kajian berikutnya dikemukakan oleh Parlina, di mana dalam artikelnya menjelaskan urgensi gugatan kelompok atau gugatan warga negara dalam perkara Mandalawangi. ${ }^{7}$ Berikutnya yaitu hasil riset Imamulhadi yang menjelaskan pentingnya putusan hakim yang memihak terhadap upaya perlindungan dan pelestarian

5 Hamid, "Penegakan Hukum Pidana Lingkungan Hidup Dalam Menanggulangi Kerugian Negara," hlm. 95.

6 Sri Laksmi Anindita, "Perkembangan Ganti Kerugian Dalam Sengketa Lingkungan Hidup," Adapher:Jurnal Hukum Acara Perdata 3, no. 2 (2017): 331-50, https://doi.org/10.36913/jhaper.v3i2.59.

7 Nurasati Parlina, "Penerapan Class Action Di Indonesia Studi Kasus Putusan Nomor 1794 K/ PDT/2004," Jumal Poros Hukum Padjadjaran 2, no. 2 (2021): 237-52, https://doi.org/10.23920/jphp.v2i2.377. 
lingkungan. ${ }^{8}$ Namun demikian, artikel-artikel tersebut belum menganalisis secara khusus perkara-perkara yang dijadikan objek penulisan. Untuk itu, tulisan ini ditujukan untuk mendalami konsistensi putusan-putusan hakim atas perkaraperkara landmark kerusakan lingkungan di beberapa tahun terakhir yaitu perkara Mandalawangi, Kalista Alam dan Sungailiat.

Kasus pertama, yaitu Mandalawangi, terjadi pada tahun 2003 antara penggugat yaitu warga Kecamatan Kadunggora, Kabupaten Garut, Provinsi Jawa Barat) dan ter gugat Perum Perhutani. Gugatan berbentuk class action ini dilakukan setelah terjadinya bencana longsor dan banjir yang menimbulkan kerugian cukup besar bagi warga. Tergugat dianggap secara langsung maupun tidak langsung telah mengubah sifat fisik lingkungan hutan menjadi tidak berfungsi sebagai mana mestinya, melakukan perubahan tata guna lahan hutan tanpa memperhatikan kelestarian lingkungan hidup. Para tergugat berdalih bahwa longsor terjadi karena faktor bencana alam. Akan tetapi penolakan tersebut tidak dapat diterima mengingat tidak terpenuhinya persyaratan untuk suatu kejadian lingkungan merupakan bencana alam. Upaya hukum yang dilakukan sampai ke Mahkamah Agung dan menghasilkan keputusan yang memenangkan para penggugat yaitu warga Kecamatan Kadunggora, Kabupaten Garut, Provinsi Jawa Barat.

Kasus kedua yaitu sengketa antara Menteri Negara Lingkungan Hidup dan Kehutanan (KLKH) sebagai penggugat melawan PT Kallista Alam sebagai tergugat. PT. Kallista Alam digugat atas tindakan pembakaran 1000 hektar lahan hutan di Rawa Tripa pada tahun 2012. Hasilnya, PT. Kallista Alam divonis bersalah dan diwajibkan untuk membayar ganti kerugian dan biaya pemulihan lahan. Vonis tersebut termuat dalam Putusan Pengadilan Negeri Meulaboh Nomor 12/Pdt.G/2012/PN.Mbo jo Putusan Pengadilan Tinggi Banda Aceh Nomor 50/PDT/2014/PT.BNA jo Putusan Mahkamah Agung Nomor 651 K/PDT/2015 jo Putusan Peninjauan Kembali Nomor 1PK/PDT/2015 tertanggal 18 April 2017. Seharusnya dengan vonis tersebut, PT. Kallista Alam melaksanakan eksekusi putusan, tetapi PT. Kallista Alam menggugat balik KLKH dengan gugatan perlawanan eksekusi ke Pengadilan Negeri Meulaboh. Pengadilan Negeri Meulaboh pada tanggal 12 April 2018 membenarkan gugatan PT. Kallista Alam dan membebaskan PT. Kallista Alam dari seluruh tuntutan hukum melalui Putusan Nomor 16/Pdt.6/2017/PN.Mbo. KLKH mengajukan banding terhadap putusan tersebut, dan terhadapnya dalam putusan Nomor Perkara 80/PDT-LH/2018/PT. BNA, Pengadilan Tinggi Banda Aceh membatalkan putusan Nomor Perkara 16/Pdt.6/2017/PN.Mbo, yang berarti PT. Kallista Alam tetap berkewajiban melaksanakan putusan dengan membayar ganti kerugian dan biaya pemulihan lahan.

8 Imamulhadi, "Perkembangan Prinsip Strict Liability Dan Precautionary Dalam Penyelesaian Sengketa Lingkungan Hidup Di Pengadilan," Mimbar Hukum - Fakultas Hukum Universitas Gadjah Mada 25, no. 3 (2014): 416-32, https://doi.org/10.22146/jmh.16070. 
Kasus yang terakhir adalah perkara Sungailiat. Pengadilan Tinggi Bangka Belitung melalui putusannya No:21/Pid/2021/PT BBL, membatalkan Putusan Pengadilan Negeri Sungailiat yang menghukum 6 Ketua RT yang menandatangani surat undangan sosialisasi rencana gugatan atas dampak bau PT BAA di Kab Bangka. Amar Putusan PT Bangka Belitung menyatakan Para Terdakwa terbukti melakukan perbuatan yang didakwakan akan tetapi perbuatan para terdakwa bukanlah merupakan tindak pidana, melepaskan Para Terdakwa dari seluruh tuntutan, dan memulihkan hak para Terdakwa dalam kemampuan, kedudukan, harkat dan martabatnya.

Tulisan ini berusaha menguraikan dua pokok permasalahan yaitu untuk menelusuri argumentasi yuridis yang menyebabkan putusan hakim berbeda-beda dalam perkara lingkungan Nomor $1794 \mathrm{~K} / \mathrm{Pdt} / 2004$ Kasus Mandalawangi, Nomor: 16/Pdt.G/2017/PN.Mbo Kasus Kalista Alam, dan Nomor 21/Pid/ 2021/PT BBL Kasus Sungailiat; dan yang kedua, apakah ketidakkonsisten hakim dalam putusan hakim dapat dimaknai sebagai pelemahan penegakan hukum lingkungan di Indonesia. Singkatnya, artikel ini bertujuan untuk memberikan pandangan hukum terhadap putusan hakim dalam memutuskan suatu perkara yang didasarkan pada ketentuan peraturan perundang-undangan maupun penemuan hukum.

\section{Metodologi}

Artikel ini disusun menggunakan metode penelitian hukum normatif. Pendekatan penelitian dilakukan dengan menggunakan pendekatan kasus dan pendekatan perundang-undangan. Sumber informasi penelitian menggunakan bahan hukum sekunder, yaitu putusan pengadilan, buku-buku hukum, artikel hukum, dan ketentuan peraturan perundangan-undangan terkait lingkungan hidup. Teknik pengumpulan data dilakukan dengan menggunakan analisis substansi (content analysis) serta penarikan kesimpulan menggunakan deduksi untuk menjawab rumusan permasalahan.

\section{Hasil dan Pembahasan}

Dinamika Putusan Hakim dalam Perkara Lingkungan Nomor 1794 K/PDT/2004, Nomor 16/PDT.G/2017/PN.MBO, dan Nomor 21/PID/ 2021/PT.BBL

Undang-Undang angka 32 Tahun 2009 tentang Perlindungan dan Pengelolaan Lingkungan Hidup mendefinisikan perlindungan serta pengelolaan lingkungan hayati sebagai upaya sistematis dan terpadu yang dilakukan dalam rangka melestarikan fungsi lingkungan hidup serta mencegah terjadinya pencemaran serta/atau kerusakan lingkungan hayati. Ruang lingkup perlindungan dan pengelolaan lingkungan hidup tersebut mencakup perencanaan, pemanfaatan, pengendalian, pemeliharaan, pengawasan dan penegakan hukum. 
Pertama, perencanaan, inventarisasi lingkungan hidup, penetapan wilayah ekoregion, serta penyusunan rencana perlindungan serta pengelolaan lingkungan hayati (RPPLH) merupakan tahap-tahap yang wajib ditempuh dalam perencanaan proteksi dan pengelolaan lingkungan hayati. Kedua, pemanfaatan sumber daya alam yang dilakukan berdasarkan RPPLH, bila RPPLH belum ada maka pelaksanaan pemanfaatan sumber daya alam didasarkan pada daya dukung dan daya tampung lingkungan hidup yang berkelanjutan. Ketiga, pengendalian terhadap pencemaran serta/atau kerusakan lingkungan hayati dilakukan buat mewujudkan pelestarian fungsi lingkungan hayati dengan pencegahan, penanggulangan serta pemulihan. Keempat, pemeliharaan lingkungan hidup dilakukan melalui upaya konservasi sumber daya alam, pencadangan asal daya alam, serta/atau pelestarian fungsi atmosfer. Kelima, pengawasan menjadi keliru satu upaya preventif pengendalian akibat lingkungan yang tidak hanya dilaksanakan oleh pemerintah pusat serta wilayah tetapi juga menuntut kiprah masyarakat. dan terakhir, penegakan hukum lingkungan hayati yang penyelesaian sengketanya mampu ditempuh melalui pengadilan atau di luar pengadilan. Salah satu tujuan primer proteksi serta pengelolaan lingkungan hayati ialah mencegah pencemaran atau perusakan lingkungan. Pencemaran serta perusakan lingkungan artinya dua hal yang tidak sama. Pencemaran lingkungan merupakan perubahan pada komponen tertentu sebab masuknya makhluk hidup, zat, tenaga dan/atau komponen lain sedangkan perusakan lingkungan adalah tindakan menyebabkan perubahan seluruh komponen lingkungan baik yang bersifat fisik, kimia dan/atau biologi.

Terhadap pencemaran dan/atau perusakan lingkungan hayati harus dilakukan penegakan hukum supaya kelestarian lingkungan hidup tetap terjaga. Penegakan aturan lingkungan merupakan upaya buat mencapai ketaatan terhadap peraturan serta persyaratan pada ketentuan hukum lingkungan yang berlaku secara umum dan individual, melalui pengawasan serta penerapan sanksi administrasi, gugatan perdata, dan pidana. Penegakan hukum administrasi lingkungan bersifat preventif (pengawasan) serta represif (sanksi administrasi) dalam kerangka menegakkan peraturan perundang-undangan lingkungan. Penegakan hukum lingkungan administrasi bisa diterapkan terhadap aktivitas yang melanggar persyaratan perizinan dan peraturan perundang-undangan. selesainya penegakan hukum administrasi lingkungan ini tak berhasil maka upaya terakhirnya artinya penegakan hukum pidana lingkungan. Penegakan hukum lingkungan ini jua mewajibkan pengintegrasian aspek transparansi, partisipasi, akuntabilitas, serta keadilan.

Kasus Mandalawangi dengan perkara Nomor 1794 K/PDT/2004 dilatar belakangi oleh kasus tanah longsor di area Hutan Mandalawangi, Garut yang dikelola oleh Perhutani. Pengaturan mengenai Perhutani sendiri diatur melalui Peraturan Pemerintah Nomor 2 Tahun 1978 jo. Keputusan Menteri Pertanian Nomor 43/KPTS/ HUM/1978 jo. Peraturan Pemerintah Nomor 53 Tahun 1999 
yang berisi bahwa Perhutani merupakan perusahaan milik negara yang diberi Hak Pengelolaan Kawasan Hutan Lindung dan Hutan Produksi di Wilayah Jawa Barat. Wilayah pengelolaan yang menjadi lingkup Perhutani dalam mengatur kawasan hutan lindung termasuk kawasan Gunung Mandalawangi Kecamatan Kadungora, Kabupaten Garut Pada tahun 1999 Perhutani melakukan perubahan pada lahan hutan Mandalawangi yang semula merupakan kawasan hutan lindung menjadi kawasan hutan produksi terbatas, perubahan atau alih fungsi tersebut telah disetujui ditandai dengan telah dikeluarkannya keputusan yang dikeluarkan oleh Menteri Kehutanan No. 419/KPTS.11/1999 yang intinya adalah mengubah status hutan lindung Mandalawangi menjadi hutan produksi terbatas serta memberi wewenang pengelolaannya kepada Perhutani sehingga terjadi longsor di area hutan Mandalawangi. ${ }^{10}$ Akibat adanya tanah longsor tersebut masyarakat di sekitar wilayah hutan Mandalawangi merasa sangat dirugikan karena perubahan lahan tersebut dan akhirnya mengajukan gugatannya kepada Direksi Perum Perhutani sebagai Tergugat I, Gubernur Provinsi Jawa Barat sebagai Tergugat II, Tergugat III dan Tergugat IV masing-masing adalah Presiden Republik Indonesia dan juga Menteri Kehutanan Indonesia. Pengajuan gugatan oleh masyarakat yang mengalami kerugian atas perubahan lahan tersebut diajukan menggunakan prosedur gugatan secara perwakilan kelompok atau class action. Masyarakat korban longsor sebagai Penggugat mendasarkan gugatannya atas perbuatan melawan hukum yang dilakukan oleh Tergugat I atau Perhutani dengan melakukan tindakan perusakan terhadap lingkungan hutan yang diatur pada Pasal 1 butir 14 Undang- Undang No. 23 Tahun 1997 tentang Pengelolaan Lingkungan Hidup jo. Pasal 48 ayat 2 Undang-Undang Nomor 41 Tahun 1999 tentang Kehutanan.

Alasan yang memberatkan dalam perkara ini karena Tergugat I telah menyimpang dari maksud dan tujuan perusahaan, sehingga menyebabkan luas hutan di Jawa Barat berkurang dari $20 \%$ menjadi $8 \%$. Tergugat III yang mengubah status hutan lindung Mandalawangi menjadi hutan produksi juga menyebabkan Tergugat I melakukan tindakan melanggar tujuan perusahaan yang melakukan penebangan tanpa reboisasi dan dibiarkan oleh Tergugat III. Selain itu, Kepala KPH Perhutani Garut juga menyatakan bahwa hutan yang seharusnya direboisasi justru disewakan kepada penduduk. Oleh karena itu, tindakan Penggugat I yang tidak melakukan reboisasi, mengubah hutan primer menjadi sekunder, menciptakan lahan kosong dan lahan garapan pertanian yang dimanfaatkan penduduk telah mengubah fisik dan/atau fungsi hutan yang dikualifikasikan sebagai perusakan hutan. Hal ini mengakibatkan longsor di area hutan

9 Imamulhadi; Sapto Hermawan and Wida Astuti, “Analysing Several ASEAN Countries' Policy for Combating Marine Plastic Litter,” Environmental Law Review 23, no. 1 (2021): 9-22, https://doi.org/10.1177/1461452921991731.

10 Rizky Bayu Permana, Dewo Baskoro, and Arie Afriansyah, "Hukum Internasional Made In Garut? Mengkritisi Status Jus Cogens Atas Prinsip Kehati-Hatian Dalam Mandalawangi,” Bina Hukum Lingkungan 5, no. 1 (2020): 153-79, https://doi.org/10.24970/bhl.v5i1.156. 
Mandalawangi dan menghancurkan pemukiman penduduk yang ternyata sudah diketahui oleh Tergugat I bahwa terdapat titik rawan longsor namun diabaikan yang menyebabkan korban jiwa dan harta benda. Sedangkan alasan yang meringankan bahwa Tergugat I telah membuat Rencana Umum Perusahaan, Rencana Lima Tahunan Perusahaan, dan Rencana Kerja Tahunan Perusahaan yang ketiganya merupakan wujud pembinaan di bidang perencanaan. Tergugat I juga telah berupaya menjaga kelestarian hutan dengan membuat Rencana Pengaturan Kelestarian Hutan untuk jangka 10 tahun, Rencana Teknik Tahunan, dan Rencana Kerja dan Anggaran Perusahaan yang di dalamnya memuat detail rencana pengelolaan Kawasan hutan. Penutupan hutan yang dilakukan oleh Tergugat I secara mendetail juga terbatas pada tanaman pinus kelompok umur II dan III, hutan alam kayu lain dan tidak produktif. Tergugat I juga sudah melaksanakan reboisasi 208.93 hektar sedangkan terciptanya lahan kosong dilakukan oleh masyarakat perambah hutan yang menyebabkan kerusakan hutan. Terkait longsor disebabkan karena intensitas hujan yang tinggi di jenis tanah merah.

Pengadilan Negeri Bandung telah mengeluarkan suatu Putusan Nomor: 49/Pdt.G/2003/PN BDG dengan amar putusannya yaitu mengabulkan gugatan masyarakat yang mengalami kerugian dengan prosedur perwakilan kelompok atau class action; menyatakan bahwa Direksi Perhutani sebagai Tergugat I, Menteri Kehutanan Republik Indonesia sebagai Tergugat III, Pemerintah Daerah Tingkat I Jawa Barat sebagai Tergugat IV dan Pemerintah Daerah tingkat II Garut sebagai Tergugat $\mathrm{V}$, seluruhnya memiliki tanggung jawab mutlak (strict liability) terhadap dampak yang timbul dikarenakan adanya longsor yang terletak di kawasan Gunung Mandalawangi, Garut. Amar putusan tersebut juga menyebutkan bahwa menghukum para tergugat untuk melakukan perbaikan atas lingkungan dan melakukan pembayaran biaya perbaikan lingkungan hutan tersebut senilai Rp 2.000.000.000,- (dua milyar rupiah); kemudian menghukum para tergugat untuk membayar ganti kerugian kepada masyarakat yang menjadi korban longsor di wilayah Gunung Mandalawangi sebesar Rp 10.000.000.000,- (sepuluh milyar rupiah) dan menyatakan bahwa putusan atas kasus lingkungan hutan Mandalawangi dilaksanakan terlebih dahulu (uitvoerbaar bejvooraad).

Kasus kerusakan lingkungan yang kedua terkait dengan kasus PT. Kallista Nomor 16/PDT.G/2017/PN.MBO yang merupakan perusahaan yang mengelolah sawit dan pembuatan minyak sawit yang banyak menimbulkan dampak negatif bagi lingkungan hidup. Bahwa pada 25 Agustus 2011 PT. Kallista Alam mendapat surat izin tentang usaha perkebunan budidaya untuk menggerakkan perkebunan kelapa sawit. Namun sebelum aktifisasi, pada bulan November 2011 pengolahan tanah tersebut terpaksa PT. Kallista Alam melakukan pengentian berdasarkan surat keputusan gubernur tentang pencabutan izin usaha perkebunan dikarenakan ketidaksesuaian titik koordinat objek dengan kenyataan sebenarnya (error in objekto). Sesuai Pengadilan Negeri Meulaboh dalam putusan 
Nomor 12 /PDT.G/2012/PN.MBO tertanggal 8 Januari 2014 jo Putusan Pengadilan Tinggi Banda Aceh Nomor: 50/PDT/2014/PT.BNA Tanggal 15 Agustus 2014 jo Putusan Mahkamah Agung Nomor 651 K/PDT/ 2015 Tanggal 28 Agustus 2015 jo Putusan Mahkamah Agung Nomor 1 PK/PDT/2015 tangal 18 April 2017, posisi batas koordinatnya adalah 98 32' 21" BT maka dapat terlihat secara jelas di mana objek gugatan dalam putusan tersebut tidak sesuai dengan kenyataan yang ada.

Pada putusan pertama di Pengadilan Negeri Meulaboh menyatakan PT Kallista Alam terbukti bersalah dan wajib melaksanakan putusan. PT. Kallista Alam melaksanaan putusan yang inkracht kepada Pengadilan Negeri Meulaboh berdasarkan surat Nomor: S-103/PSLH/GKM.1/11/2016 yang meminta eksekusi. Namun dalam Pengadilan Negeri Meulaboh menolak dan tidak mendukung atas pelaksanaan atau eksekusi dari putusan Mahkamah Agung serta mengeluarkan surat Nomor 12/Pen.Pdt.Eks/2016/PN-Mbo yang berisikan menunda pelaksanaan eksekusi dari mahkamah agung hingga ada putusan peninjauan kembali yang diajukan oleh PT. Kallista Alam. Hal ini jelas melanggar hukum acara, bahwa peninjauan kembali tidak menunda eksekusi karena kasus ini merupakan upaya hukum terakhir, dan ironisnya terdapat pelanggaran hukum acara dilakukan oleh peradilan tersebut. Kemudian untuk kedua kalinya Kementerian Lingkungan Hidup dan Kehutanan mengajukan aanmaning terkait dengan surat Nomor 12/Pen.Pdt.Eks/2016/PN-Mbo.

Putusan Nomor 1 PK/PDT/2017 Mahkamah Agung menolak Peninjauan Kembali PT. Kallista Alam dan menyatakan bersalah telah melanggar ketentuan dalam putusan Pengadilan Negeri Meulaboh. Sehingga muncullah surat nomor 5793/DK-P/VI/2017 berkaitan dengan PT. Kallista Alam yang meminta Perlindungan terhadap Pengadilan Negeri Meulaboh. Dari hal tersebut, Pengadilan Negeri Meulaboh mengeluarkan putusan Nomor 16/Pdt.G/2017/ PN yang menyatakan putusan Mahkamah Agung pada Tingkat Kasasi dan Peninjauan Kembali tidak dapat dimintakan pertanggungjawaban karena tidak memiliki titel eksekutorial. ${ }^{11}$ Alasan yang memberatkan PT. Kallista Alam adalah lokasi kebakaran sesuai dengan titik koordinat izin usaha yang dimiliki oleh PT. Kallista Alam, sehingga kerusakan yang ditimbulkan dari kebakaran lahan merupakan konsekuensi logis bahwa pencemar bertanggungjawab untuk mengganti rugi (polluter must pay principle). Pembukaan lahan dengan pembakaran hutan jelas perbuatan melanggar hukum termasuk dampak yang ditimbulkan dari pembakaran hutan.

Dalam kasus kerusakan lingkungan yang ketiga, yaitu Sungailiat, melibatkan warga Kenangan, Kecamatan Sungailiat Kabupaten Bangka, yang terdiri dari Robandi, Muhammad Yusuf, Mulyadi, Yamsul Effendi, Heti Rukmana, dan

11 Elsa Nastiti Dama Yanti, "Efektivitas Putusan Pengadilan Pidana Dan Perdata Kasus Pembakaran Lahan (Studi Kasus Pembakaran Lahan Berkelanjutan Oleh PT. Kallista Alam)," ResearchGate 1, no. 1 (2020): 11-20. 
Aditama, yang masing-masing merupakan mantan ketua Rukun Tetangga (RT) II, III, IV, V, VI dan VII. Kasus ini diawali dari penolakan keenam mantan Ketua RT tersebut terhadap bantuan yang diberikan berupa bantuan pangan di mana diberikan PT Bangka Asindo Agri (BAA) terhadap warga masyarakat yang berada di wilayah administrasi mereka, yang selanjutnya merembet ke hal lain hingga keenamnya didakwa telah melakukan perbuatan sebagaimana diatur dalam pasal 228 KUHP jo pasal 55 ayat 1 ke 1 KUHP, atas tindakan mereka karena telah bersama-sama telah sepakat dan menandatangani surat undangan yang isinya adalah sosialisasi mengenai rencana persetujuan terhadap pemberian kuasa kepada Advokat Zaidan dalam menggugat hukum PT Bangka Asindo Agri (PT. BAA) atas bau yang ditimbulkan dari produksi tepung tapioca, surat tertanggal 24 Mei 2020. Surat undangan sosialisasi ditandatangani oleh keenam orang tersebut dengan memposisikan diri seolah-olah masih sebagai Ketua RT dan menggunakan stempel RT II, RT III, RT IV, RT V, RT VI dan RT VII padahal pada saat itu mereka telah melakukan pengunduran diri sebagai Ketua RT melalui surat pengunduran diri masing-masing tertanggal 22 April 2020 yang ditanda tangani di atas materai. Melalui putusan pengadilan tingkat pertama yaitu Putusan Pengadilan Negeri Sungailiat Nomor 475/Pid.Sus/2020/PN.Sgl tanggal 6 April 2021. keenamnya dinyatakan telah terbukti melakukan suatu tindak pidana di mana kesemuanya bersama-sama dengan sengaja dan sadar telah memakai tanda kepangkatan atau melakukan suatu perbuatan yang di dalamnya termasuk jabatan yang tidak dijabatnya atau yang ia sementara dihentikan daripadanya" dan dikenakan pidana penjara karenanya.

Baik dari pihak terdakwa dan juga penuntut umum mengajukan permohonan banding atas Putusan Nomor 475/Pid.Sus/2020/PN.Sgl tersebut, dan permohonan banding secara formal diterima. Kemudian Pengadilan Tinggi Bangka Belitung Nomor 21/PID/2021/PT. BBL menjatuhkan putusan untuk membatalkan putusan Pengadilan Negeri Sungailiat Nomor 475/Pid.Sus/2020/ PN Sgl tanggal 6 April 2021 sebelumnya. Dalam putusan banding tersebut juga menyatakan bahwa para terdakwa terbukti melakukan perbuatan sebagaimana yang didakwakan oleh Penuntut Umum, namun perbuatan Para Terdakwa tersebut bukan atau tidak termasuk Tindak Pidana dan atas dasar tersebut semua terdakwa dilepaskan dari seluruh tuntutan Pidana. Alasan yang memberatkan dalam perkara ini bahwa terbukti menggunakan tanda kepangkatan atau perbuatan yang termasuk dalam jabatannya secara Bersama-sama untuk melakukan, menyuruh lakukan dan turut serta melakukan hal yang merugikan masyarakat.

Analisis terkait dengan perbedaan argumentasi yuridis dari ketiga putusan tersebut adalah di mana pada kasus Mandalawangi hakim dalam putusan kasus tersebut telah berani keluar dari aturan perundang-undangan yang dilakukan dengan melihat fakta-fakta di lapangan dengan memperluas konsep strict liability ini dengan tidak mendasarkan pada Pasal 35 UUPLH 1997 dengan mengklasifikasikan pengelolaan hutan lindung sebagai kegiatan yang berbahaya (extra 
bazardous) atau tidak lazim (non natural use). ${ }^{12}$ Hakim mendasarkan putusannya pada asas in dubio pro natura yang artinya bahwa apabila hakim mengalami keraguraguan dalam memutuskan perkara maka hakim mengedepankan perlindungan lingkungan dalam putusannya. Asas tersebut merupakan turunan dari asas kehatihatian atau precautionary principle dengan bentuk Analisa Mengenai Dampak Lingkungan yang dijelaskan didalam UU No. 32 tahun 2009 tentang Perlindungan dan Pengelolaan Lingkungan Hidup. Hakim sendiri di dalam kasus ini telah berani untuk menemukan keadilan dengan keluar dari peraturan perundang-undangan dan memposisikan dirinya sebagai penemu hukum atau istilah lainnya adalah rechts vinding. Pada putusan di mana hakim menyatakan:

Dalam keadaan kurangnya ilmu pengetahuan, termasuk adanya pertentangan pendapat yang saling mengecualikan, sementara keadaan lingkungan sudah sangat rusa, maka pengadilan dalam kasus ini memilih dan juga berpedoman pada prinsip hokum lingkungan hidup atau yang dikenal sebagai precautionary principle, prinsip ke-15 yang terkandung dalam prinsip pembangunan berkelanjutan (United Nation Conference on Environment and Development). Walaupun prinsip ini belum masuk ke dalam perundang-undangan Indonesia, tetapi Indonesia sebagai anggota dalam konferensi tersebut, maka semangat dari prinsip ini dapat dipedomani dan diperkuat dalam mengisi kekosongan hukum dalam praktik. Hakim secara tidak langsung telah mengubah acuan hukum soft law di mana keputusan memperluas strict liability tersebut yang tidak sesuai dengan undang-undang di Indonesia dan mengubahnya menjadi hard law dan dapat digunakan menjadi acuan putusan pengadilan dengan mendasarkan kepada prinsip Deklarasi Rio tahun 1992 ke dalam putusan kasus Hutan Mandalawangi.

Pada kasus PT. Kallista Alam dalam penegakan hukum perdata menghasilkan beberapa putusan yang berbeda-beda. Dalam gugatannya menjadi hal yang patut diapresiasi, Namun dalam permasalahannya gugatan ini tidak terealisasi dengan baik hanya menyentuh kerusakan lahan yang ditimbulkan dari kasus kerusakan hutan tersebut. Tindakan yang dilakukan Pengadilan Meulaboh dalam hal ini telah bertindak melampaui kewenangan dan tidak konsisten dalam memberikan keadilan. Dalam prinsip hukum yang berkaitan dengan prinsip kebebasan hakim yang memiliki kebebasan yang absolut dengan menyelesaikan perkara secara obyektif berdasarkan hukum yang berlaku, yang bebas dari pengaruh pihak manapun dalam proses pengambilan putusan tersebut. Dan tentunya dalam pertimbangan putusan hakim hanya terikat pada fakta-fakta yang relevan dan kaidah hukum yang menjadi landasan hukum. Dengan demikian dalam pemutusan sengketa harus dijalankan dengan penuh tanggung jawab yang besar sebab dari putusan hakim tersebut yang nantinya akan membawa dampak yang sangat jauh pada kehidupan orang lain.

Penerapan prinsip hukum ini berbanding terbalik dalam putusan pengadilan Meulaboh, dan hakim tidak sepenuhnya menerapkan prinsip kebebasan dalam

12 Scheffer M.W.A, The Precautionary and Preventions Principles, 1966. 
kasus ini. Bahwa tindakan yang dilakukan oleh PT. Kallista Alam seakan tidak mengindahkan ketentuan dalam Undang-Undang Nomor 32 Tahun 2009 tentang Perlindungan dan Pengolahan Lingkungan Hidup. Kerusakan dikarenakan adanya pembukaan lahan dengan metode pembakaran yang berakibat rusaknya lahan gambut dan lepasnya efek gas rumah kaca hingga kebakaran massif. Tetapi terkait dengan putusan PT. Kallista Alam hakim hanya condong ke pihak tersebut dan dinilai telah menggagalkan pelaksanaan eksekusi putusan sebelumnya dan memperlihatkan pada keberpihakan perusakan lingkungan. Bahwa Pengadilan Meulaboh tidak hanya sekali saja melakukan penundaan PT. Kallista Alam tetapi sebelumnya Pengadilan Meulaboh pun menyetujui terhadap penundaan pelaksanaan putusan dengan didasari alasan karena adanya upaya hukum luar biasa, padahal pengajuan peninjauan kembali tidak dapat menjadi alasan dalam penundaan eksekusi atau putusan yang telah memiliki kekuatan hukum tetap.

Lain halnya dengan kasus Mandalawangi dan Kallista Alam, dalam Kasus Sungailiat hakim pada pengadilan tingkat pertama mengesampingkan konsepsi mengenai Pejuang Lingkungan Hidup yang seharusnya dilindungi dari gugatan, Hakim menilai perbuatan para Terdakwa tidak sebagai pejuang lingkungan hidup. Namun dengan adanya upaya banding, Hakim tingkat banding memberikan argumentasi yuridis yang condong berpihak pada pejuang lingkungan hidup. Hakim menganggap bahwa "Partisipasi" dapat dimaknai sebagai unsur dari Pasal 66 Undang-undang No. 32 tahun 2009 apabila menilik pada Memorie Van Toelichting Undang-undang No. 32 tahun 2009 yang diartikan secara rinci bahwa dalam pengaturan Pasal 66 Undang-undang No.32 tahun 2009 tersebut adalah satu kesatuan bagian ketentuan tentang hak yang salah satunya dapat dilaksanakan melalui "Partisipasi", selanjutnya makna "Memperjuangkan" sendiri merupakan aktifitas yang mana perbuatannya dapat berbentuk Partisipasi, maka konstruksi pasal 66 Undang-undang No.32 tahun 2009 mengandung 2 (dua) unsur utama Anti Strategic Lawsuit Against Public Participation (Anti-SLAPP) yaitu Partisipasi atau ekspresi dan Kepentingan Publik (lingkungan). Dalam huruf B angka 4 SK KMA Nomor 036/KMA/SK/II/2013 tentang Pemberlakuan Pedoman Penanganan Perkara Lingkungan Hidup yang di dalamnya disebutkan di mana untuk memutuskan sebagaimana Pasal 66 Undang-undang No. 32 tahun 2009 bahwa gugatan Penggugat atau pelaporan terhadap tindak pidana dari Pemohon merupakan SLAPP yang tentunya dapat dikemukakan baik dalam provisi, eksepsi atau dalam gugatan rekonvensi dan/atau pembelaan dan hal tersebut haruslah diputuskan terlebih dahulu dalam suatu putusan sela.

Dalam putusannya Hakim banding memuat pertimbangan hukum mengenai konsepsi Anti Strategic Lawsuit Against Public Participation (Anti-SLAPP) yang diatur dalam Pasal 66 UU No. 32 Tahun 2009 yang dihubungkan dengan Huruf B angka 4 SK KMA Nomor 36/KMA/SK/II/2013 tentang Pemberlakuan Pedoman Penanganan Perkara Lingkungan Hidup, oleh sebab itu, tindakan Para Terdakwa dianggap sebagai tindakan partisipasi dalam suatu perjuangan bagi 
lingkungan hidup yang terjamin bersih serta sehat, di mana tindakan tersebut tidaklah dapat digugat ataupun dilaporkan pihak Kepolisian sebagaimana bunyi Pasal 66 Undang-undang No.32 tahun 2009 di mana unsur dari ANTI SLAPP tidaklah bisa dituntut baik secara Pidana ataupun Perdata.

\section{Perbedaan Putusan Hakim dan Penegakan Hukum Lingkungan di Indonesia}

Mertokusumo ${ }^{13}$ menyatakan bahwa putusan hakim artinya suatu pernyataan yang oleh hakim, menjadi pejabat yang diberi kewenangan yang diucapkan di persidangan dan bertujuan mengakhiri atau menyelesaikan suatu kasus atau konkurensi antara para pihak. Sedangkan berdasarkan Mulyadi, ${ }^{14}$ putusan hakim adalah putusan yang diucapkan oleh hakim dalam persidangan, di mana dibacakan terbuka untuk umum setelah melalui proses dan prosedural hukum acara pidana pada umumnya berisikan amar pemidanaan bebas atau pelepasan dari segala tuntutan hukum dibuat pada bentuk tertulis dengan tujuan menyelesaikan masalah. Asas-asas Putusan Hakim dijelaskan dalam pasal 1778 HIR, Pasal 189 Rbg dan pasal 19 yang ada pada Undang-Undang nomor 48 Tahun 2009 perihal kekuasaan kehakiman, di antaranya. Pertama, asas memuat dasar alasan yang kentara serta rinci, menurut asas ini bahwa setiap puutusan yang dijatuhkan oleh hakim wajib sesuai pertimbangan yang kentara dan cukup sebab putusan yang tidak memenuhi ketentuan itu mengkategorikan putusan yang tidak cukup pertimbangan atau onvoldoende gemotiveerd (insuffcient judgement). Alasan-alasan hukum yang menjadi dasar pertimbangan bertitik tolak dari ketentuan pasal tertentu peraturan perundang-undangan, aturan kebiasaan, yurisprudensi, atau doktrin hukum. kedua, wajib mengadili seluruh bagian gugatan adalah putusan harus menilik dan mengadili setiap bagian gugatan yang diajukan secara menyeluruh tanpa terkecuali, tidak boleh hanya mempelajari sebagian saja. Ketiga, tidak boleh mengabulkan melebihi yang diminta yang biasa diklaim ultra petitum partium yaitu bahwa putusan tidak boleh melebihi apa yang diminta pada gugatan. Keempat, diucapkan di muka umum yaitu putusan hakim dianggap sah bila diucapkan dalam sidang pengadilan yang terbuka untuk umum.

Putusan hakim mengkategorikan menjadi putusan sela serta putusan akhir. Putusan sela ialah putusan yang bersifat ad interim yang diucapkan secara terpisah sebelum dijatuhkannya putusan akhir akan tetapi putusan sela ini hanya ditulis dalam berita acara persidangan tidak didesain dengan putusan tersendiri. dalam teori serta praktiknya, putusan sela mengkategorikan dalam beberapa macam putusan, di antaranya putusan preparatoir, putusan interlocutoir, putusan incidenteel, serta putusan provisioneel. Sedangkan putusan akhir merupakan pernyataan hakim menjadi pejabat

13 Sudikno Mertokusumo, Hukum Acara Perdata (Yogyakarta: Liberty, 1993), hlm. 174.

14 Lilik Mulyadi, Kompilasi Hukum Pidana Dalam Prespektif Teoritis Dan Prakter Pradilan (Jakarta: Mandar Maju, 2007), hlm. 127. 
negara yang diberi kewenangan untuk diucapkan pada persidangan serta bertujuan untuk mengakhiri atau menuntaskan masalah atau sengketa antara pihak yang berperkara serta diajukan kepada pengadilan. ${ }^{15}$ Melandaskan pada sifat putusan terdapat putusan declaratoir, putusan constitutief, dan putusan condemnatoir. Sedangkan dicermati dari isi putusan ada putusan dalam aspek kehadiran para pihak (putusan gugur, putusan verstek dan putusan contradictoir.

Konsistensi putusan hakim memiliki makna adanya kesepahaman hakim dalam memandang suatu permasalahan hukum atau pertanyaan hukum. Konsistensi putusan sendiri dapat memberikan kepastian hukum dan juga akan meningkatkan kepercayaan publik terhadap peradilan itu sendiri. Adanya ketidakkonsistenan hakim dalam mengeluarkan putusan bisa saja menjadi faktor pelemahan penegakan hukum lingkungan di Indonesia. Dalam pelaksanaannya pada kasus Mandalawangi hakim dapat dikatakan tidak konsisten dalam mengeluarkan putusan karena penerapan Precautionary Principle dalam pertimbangannya Majelis Hakim tingkat pertama mendasarkan putusannya pada prinsip ke 15 yang terkandung dalam asas Pembangunan Berkelanjutan pada Konferensi Rio tanggal 12 Juni 1992, putusan tersebut dinilai tidak memiliki dasar hukum dikarenakan belum menjadi hukum positif di Indonesia, dan alasan tersebut dianggap kurang tepat apabila dijadikan jalan keluar untuk mengisi kekosongan hukum, dikarenakan sudah ada hukum positif yang mengatur masalah lingkungan hidup dan kehutanan, yaitu UUPLH pada Pasal 3, 6, 14, 15, 34 dan 35 dan UU No. 41 Tahun 1999 tentang Kehutanan pada Pasal 43, 45, 48,60 dan $68 .^{16}$

Namun, Hakim tetap pada pendiriannya di mana dalam pertimbangannya memberikan alasan bahwa suatu ketentuan hukum Internasional dapat pula digunakan oleh hakim nasional apabila telah dipandang sebagai "jus cogen" sehingga hakim sendiri beranggapan bahwa dirinya tidak salah dalam menerapkan hukum di mana hakim sendiri mengadopsi dari ketentuan hukum Internasional. Pertimbangan hakim tersebut sudah benar dalam menerapkan Precautionary Principle walaupun pada UU Nomor 23 Tahun 1997 belum dianut Precautionary Principle sebagaimana telah dianut UU Nomor 32 Tahun 2009. Namun, hukum lingkungan sendiri pada umumnya cukup banyak mendasarkan pada ketentuan-ketentuan yang ada pada hukum internasional dan hakim sendiri mendasarkan putusannya atas dasar keadilan bagi masyarakat korban longsor Mandalawangi tersebut. Maka dapat dikatakan bahwa ketidakkonsisten hakim dalam putusan Mandalawangi ini tidak menjadi pelemahan penegakan hukum di Indonesia justru memberikan pandangan baru mengenai kasus hukum lingkungan di Indonesia dan memberikan keadilan dan

15 Abdul Manan, Penerapan Hukum Acara Perdata Di Lingkungan Pengadilan Agama (Jakarta: Kencana, 2008), hlm. 308.

16 Loura Hardjaloka, "Ketepatan HAKIM DALAM Penerapan Precautionary Principle Sebagai 'Ius Cogen' Dalam Kasus Gunung Mandalawangi” 5, no. 2 (2012): 134-53, https://doi.org/10.29123/jy.v5i2.132. 
kepastian hukum bagi masyarakat yang terkena dampak dari kasus lingkungan tersebut.

Kasus Mandalawangi ini menjadi kasus yang dapat dikatakan telah memberi dampak yang cukup penting dalam penanganan atau litigasi kasus lingkungan di Indonesia. Kasus ini juga memberikan gambaran mengenai putusan hakim yang memberi keadilan substantif. Walaupun sebenarnya penerapan ius cogen dalam putusan hakim tersebut perlu dikaji ulang bahwasanya tidak ada argumen dari para pihak yang bersengketa dari tingkat pertama sampai dengan tingkat kasasi. Namun hakim tetap pada pandangannya di mana penerapan ius cogen penting dalam memutuskan kasus Mandalawangi itu sendiri yang mengedepankan unsur lingkungan dan mengadopsi hukum internasional kepada hukum nasional di mana lebih spesifik dalam mengatur klasifikasi pengelolaan hutan lindung.

Namun, ketidakkonsistenan hakim dalam putusan juga dapat menjadi indikasi pelemahan penegakan hukum di Indonesia. Terkait dengan kasus PT. Kallista Alam berdasarkan berbagai pelaksanaan putusan perdata pada kenyatannya jauh dari kata efektif karena terjadi inkonsistensi putusan Pengadilan Negeri Meulaboh yang awalnya memutuskan perkara tersebut dengan menetapkan PT. Kallista Alam bersalah, namun pada akhirnya mengeluarkan putusan yang menyatakan untuk melindungi PT. Kallista Alam dari berbagai tuntutan dan memberi perlindungan hukum. Kemudian adanya ketidaksewenangan dari Pengadilan Meulaboh yang menyatakan untuk tidak melaksanakan putusan Mahkamah Agung sebelum adanya putusan Peninjauan Kembali sesuai dengan Pasal 66 ayat (2) UU MA menyatakan bahwa peninjuan kembali tidak menunda pelaksanaan putusan yang telah berkekuatan hukum tetap.

Pertimbangan hakim pada Pengadilan Negeri Meulaboh memunculkan bahwa kekuasaan kehakiman hanya menjadi alat untuk mengesampingkan kepastian hukum yang sudah seharusnya menjadi tujuan dari penegakan hukum dan berbanding terbalik menjadi jauh dari tujuan penegakan hukum yaitu keadilan, kemanfaatan dan kepastian hukum. Gugatan dari PT. Kallista Alam yang telah diterima oleh Pengadilan Negeri Meulaboh berkaitan dengan pembahasan error in objecto yang sebenarnya persolan tersebut tidak diambil kembali dikarenakan objek telah diperiksa dalam proses persidangan, dan segala upaya hukum telah dilakukan dan hakim setiap tingkat menerangkan PT. Kallista Alam terbukti memenuhi perbuatan melawan hukum. Adapun upaya hukum yang dilakukan dengan mengajukan penentangan eksekusi yang seharusnya dilaksanakan oleh pihak ketiga yang berkepentingan, bukan oleh PT. Kallista Alam.

Berdasarkan dari Koalisi Anti Mafia Hutan telah menelaah 3 kejanggalan dalam penerapan hukum terkait kasus PT. Kallista Alam yaitu: ${ }^{17}$ Pertama, Tercantum amar putusan poin 4 yang menerangkan putusan Mahkamah Agung Nomor 1/PK/PDT/2015 tanggal 18 April 2017 tidak memiliki titel eksekutorial

17 Kallista Alam, "6 Mei 2018 Berita Buruk Bagi Lingkungan: Berkomplotnya Mafia Peradilan Dengan Korporasi Perusak Hutan ?,” 2018. 
terhadap PT. Kallista Alam. Kedua. Majelis hakim keliru dalam menerapkan hukum. Dalam putusan No. 16/Pdt-G/2017/PN.Mbo hakim telah menggugurkan segala tanggung jawab PT. Kallista Alam yang membatalkan putusan Mahkamah Agung, pada dasarnya dalam pasal 195 HIR terkait upaya perlawanan suatu putusan wajib dilaksanakan oleh pengadilan yang lebih tinggi. Ketiga, Majelis hakim telah keliru memahami objek perkara. Yaitu lokasi yang berada di luar Hak Guna Usaha, tetapi PT. Kallista Alam meminta agar terlepas dari tanggung jawab kerugian lingungan hidup di lokasi Hak Guna Usahanya

Bahwa Majelis Hakim keliru dalam putusan yang mengamini gugatan PT. Kallista Alam dengan tidak mendalami muatan putusan sebelumnya. Dalam putusan PN Meulaboh dapat diduga untuk menggagalkan pelaksanaan putusan sebelumnya, dan lebih berpihak terhadap perusakan lingkungan.

Bahwa dalam Kasus Sungailiat perbedaan pendapat antara Hakim pada Tingkat Pertama dengan Hakim Tingkat Banding menunjukkan adanya perkembangan hukum yang penting dalam pemaknaan Pejuang Lingkungan Hidup. Hakim tingkat Banding dalam pertimbangan hukumnya mengaitkan persoalan tersebut dengan Huruf B angka 4 SK KMA Nomor 36/KMA/SK/II/2013 tentang Pemberlakuan Pedoman Penanganan Perkara Lingkungan Hidup, di mana menyebutkan di mana dalam konteks penanganan perkara, maka seorang hakim dalam putusannya harus mempertimbangkan kemampuan hukuman yang dijatuhkan untuk memberikan efek jera, menguatkan mekanisme pengawasan untuk menjamin tidak berlanjutnya pelanggaran dan terlindunginya hak masyarakat atas lingkungan hidup yang baik dan sehat. ${ }^{18} \mathrm{Hal}$ ini juga sejalan dengan teori hukum responsif bahwa hukum harus kompeten, adil, dan harus memperdulikan keinginan publik dan memiliki komitmen dalam mencapai keadilan. Hukum merespon terhadap kebutuhan sosial dan penegakan hukum yang lebih responsif pada nilai yang hidup di masyarakat. Dalam hal ini masyarakat membutuhkan haknya untuk dilindungi atas lingkungan hidup yang sehat.

Dalam putusannya Hakim banding mengangkat isu indikasi mengenai SLAPP yang terjadi dan menganggap bahwa terhadap perbuatan para Terdakwa merupakan bentuk partisipasi yang memperjuangkan tentang kepentingan lingkungan hidup yang terjadi di wilayah mereka dan tepat dikatakan bahwa para Terdakwa merupakan pejuang lingkungan hidup. Dapat terlihat jelas bahwa hal ini menunjukkan dukungan terhadap pejuang lingkungan hidup. Konsepsi perlindungan terhadap pejuang lingkungan hidup yang tampak dalam putusan ini dapat diartikan sebagai perkembangan hukum yang penting, ${ }^{19}$ di mana dapat mem-

18 Mahkamah Agung Republik Indonesia, "Surat Keputusan Mahkamah Agung RI No. 36/KMA/SK/II/2013 Tentang Pemberlakuan Pedoman Penanganan Perkara Lingkungan Hidup.," 2013.

19 Indonesia Environmental and Law, "Proyeksi Keberlanjutan Lingkungan Hidup Di Tengah Upaya Pemulihan Ekonomi,” 2021. 
berikan pengaruh pertimbangan terhadap kasus-kasus kerugian lingkungan yang dapat terjadi kedepannya.

Tabel 1. Ringkasan Putusan

\begin{tabular}{|c|c|c|c|}
\hline Nomor Putusan & Lokasi & $\begin{array}{l}\text { Tindak } \\
\text { Pidana yang } \\
\text { Dilakukan }\end{array}$ & Amar Putusan \\
\hline $1794 \mathrm{~K} / \mathrm{Pdt} / 2004$ & $\begin{array}{l}\text { Hutan } \\
\text { Mandalawangi, } \\
\text { Kabupaten } \\
\text { Garut, Provinsi } \\
\text { Jawa Barat }\end{array}$ & $\begin{array}{l}\text { Alih fungsi } \\
\text { hutan dan } \\
\text { penebangan } \\
\text { tanpa } \\
\text { reboisasi } \\
\text { yang } \\
\text { menyebabk } \\
\text { an longsor }\end{array}$ & $\begin{array}{l}\text { Tergugat I, Tergugat III, Tergugat IV, } \\
\text { dan Tergugat V bertanggung jawab se- } \\
\text { cara mutlak (strict liability) atas dampak } \\
\text { yang ditimbulkan oleh adanya longsor } \\
\text { kawasan hutan Gunung Mandalawangi } \\
\text { serta menghukum Tergugat I, Tergugat } \\
\text { III, Tergugat IV, dan Tergugat V untuk } \\
\text { melakukan pemulihan keadaan lingkung- } \\
\text { an di areal hutan Gunung Mandalawangi }\end{array}$ \\
\hline $\begin{array}{l}\text { 16/Pdt.G/2017/P } \\
\text { N Mbo }\end{array}$ & $\begin{array}{l}\text { Kebun Kelapa } \\
\text { Sawit, } \\
\text { Kabupaten } \\
\text { Nagan Raya, } \\
\text { Propinsi Aceh }\end{array}$ & $\begin{array}{l}\text { Pembakara } \\
\mathrm{n} \text { hutan dan } \\
\text { perusakan } \\
\text { lingkungan } \\
\text { oleh PT. } \\
\text { Kallista } \\
\text { Alam }\end{array}$ & $\begin{array}{l}\text { Putusan Mahkamah Agung Nomor } 651 \\
\text { K/PDT/2015 Tanggal } 28 \text { Agustus } 2015 \\
\text { Jo Putusan Mahkamah Agung Nomor } 1 \\
\text { PK/PDT/2017 tanggal } 18 \text { April } 2017 \\
\text { yang berisikan tentang gugatan pembaka- } \\
\text { ran hutan tidak bisa dimintakan pertang- } \\
\text { gungjawaban hukumnya kepada PT. } \\
\text { Kallista Alam, dan Putusan Mahkamah } \\
\text { Agung Nomor } 1 \text { PK/PDT/ } 2017 \text { tang- } \\
\text { gal } 18 \text { April } 2017 \text { tidak mempunyai titel } \\
\text { eksekutorial terhadap PT Kallista Alam }\end{array}$ \\
\hline $\begin{array}{l}\text { 21/PID/2021/PT } \\
\text { BBL }\end{array}$ & $\begin{array}{l}\text { Kabupaten } \\
\text { Bangka, } \\
\text { Propinsi Bangka } \\
\text { Belitung }\end{array}$ & $\begin{array}{l}\text { Tindak } \\
\text { pidana } \\
\text { menyalahgu } \\
\text { nakan } \\
\text { jabatan } \\
\text { dan/ atau } \\
\text { wewenang } \\
\text { yang } \\
\text { merugikan } \\
\text { masyarakat }\end{array}$ & $\begin{array}{l}\text { Menyatakan terdakwa I. Robandi als } \\
\text { Abah bin Rahim (Alm), terdakwa II. } \\
\text { Muhammad Yusuf als Yusuf bin Seman } \\
\text { (alm), terdakwa III. Mulyadi als Aak bin } \\
\text { Abdul Latif, Terdakwa IV. Syamsul } \\
\text { Effendi als Fendi bin Darwis, Terdakwa } \\
\text { V. Heti Rukmana als Heti binti Maryadi, } \\
\text { dan Terdakwa VI. Aditama als Adi bin } \\
\text { Sanadi Agani (Alm) tersebut di atas } \\
\text { terbukti melakukan perbuatan sebagai- } \\
\text { mana yang didakwakan oleh Penuntut } \\
\text { Umum dalam dakwaan Pertama maupun } \\
\text { Kedua, akan tetapi perbuatan Para } \\
\text { Terdakwa tersebut bukanlah merupakan } \\
\text { Tindak Pidana }\end{array}$ \\
\hline
\end{tabular}

Sumber: diolab penulis, 2021 
Dari perbedaan putusan pada table 1 di atas, maka penegakan hukum terkait praktiknya tidaklah sederhana. Sebab terkait proses pembuktiannya sangat berbelit-belit, dalam menyelesaikan suatu perkara dalam konteks lingkungan hidup tidaklah cukup hanya dengan mengimplementasikan suatu ketentuanketentuan hukum yang ada di dalamnya, tetapi juga diperhatikan pentingnya judicial activism yang dilakukan dengan penemuan hukum dan penciptaan hukum dalam suatu putusannya yang bertujuan untuk melahirkan keadilan baik manusia dan lingkungan agar terpeliharanya lingkungan yang terjamin. Dalam putusannya hakim tentunya wajib dan harus memahami suatu permohonan hak gugat yang mana telah diajukan oleh pihak-pihak bersangkutan, maka kepentingan tersebut tidak dalam bentuk ganti kerugian yang dialami korban saja namun juga harus meliputi ganti kerugian untuk pemulihan lingkungan yang tercemar atau rusak akibat perbuatan pelaku.

Masalah lingkungan dalam hukum pidana memberikan sedikit penawaran kepada masyarakat mengenai kerusakan yang dialami lingkungan dengan memberikan ancaman pidana pelaku pencemaran. Namun sekalipun adanya pemidanaan terhadap pelaku, kerusakan lingkungan pun sudah terjadi dan tidak akan pulih atau dalam putusannya pengadilan dapat mengharuskan pelaku memperbaiki kerusakan tetapi ada hakim yang masih mengindahkan ketentuan terkait memperbaiki lingkungan yang rusak tersebut dan condong kepada perusak lingkungan. Sehingga dari putusan tersebutlah berpengaruh pada putusan yang berbeda menimbulkan ketidakkonsistenan hakim.

Dalam keberlangsungannya, dengan adanya ketidakkonsistenan putusan terhadap kasus-kasus kerugian lingkungan dapat dimaknai sebagai bentuk pelemahan hukum lingkungan di Indonesia, tetapi juga tidak menutup kemungkinan ketidakkonsistenan tersebut dapat dimaknai sebagai bentuk kepastian hukum yang diberikan lebih dari sekedar prosedur hukum yang ada, dan menandakan adanya perkembangan hukum yang dapat berpengaruh terhadap kepastiankepastian hukum dalam kasus kerugian lingkungan selanjutnya.

\section{Kesimpulan}

Dilematika pengaturan di dalam hukum positif yang memberikan ruang kebebasan bagi hakim dalam menjatuhkan putusan serta interpretasi independensi hakim dalam kaitannya menyatakan perbedaan pendapat (dissenting opinion) pada sebuah putusan lingkungan hidup memang menjadi paradoks. Timbulnya ketidakkonsisten hakim dalam putusan lingkungan hidup dapat dimaknai sebagai pelemahan penegakan hukum lingkungan di Indonesia, namun juga dapat dimaknai sebagai pemberi pandangan baru dan kepastian hukum lingkungan di Indonesia. Pada kasus Mandalawangi hakim dapat dinilai tidak konsisten dalam penerapan putusan dengan tidak mendasarkan putusannya pada peraturan perundang-undangan mengenai lingkungan di Indonesia, namun ketidakkonsistenan tersebut memberikan kepastian hukum yang lebih dari sekedar prosedur hukum 
yang ada. Terkait kasus Kallista Alam ketidakkonsisten Hakim dimaknai sebagai pelemahan penegakan Hukum karena Pertimbangan putusan hakim memunculkan bahwa kekuasaan kehakiman hanya menjadi alat untuk mengesampingkan kepastian hukum yang sudah seharusnya menjadi tujuan dari penegakan hukum. Dalam putusan Sungailiat perbedaan argumentasi hakim mengenai konsepsi Pejuang Lingkungan Hidup menunjukkan adanya perkembangan hukum yang penting dalam pemaknaan konsep tersebut.

\section{Daftar Pustaka}

Alam, Kallista. "6 Mei 2018 Berita Buruk Bagi Lingkungan: Berkomplotnya Mafia Peradilan Dengan Korporasi Perusak Hutan ?,” 2018.

Anindita, Sri Laksmi. "Perkembangan Ganti Kerugian Dalam Sengketa Lingkungan Hidup." Adapher:Jurnal Hukum Acara Perdata 3, no. 2 (2017): 331-50. https://doi.org/10.36913/jhaper.v3i2.59.

Dama Yanti, Elsa Nastiti. "Efektivitas Putusan Pengadilan Pidana Dan Perdata Kasus Pembakaran Lahan (Studi Kasus Pembakaran Lahan Berkelanjutan Oleh PT. Kallista Alam)." ResearchGate 1, no. 1 (2020): 11-20.

Environmental, Indonesia, and Law. "Proyeksi Keberlanjutan Lingkungan Hidup Di Tengah Upaya Pemulihan Ekonomi," 2021.

Hamid, Muhammad Amin. "Penegakan Hukum Pidana Lingkungan Hidup Dalam Menanggulangi Kerugian Negara." Legal Pluralism: Journal of Law Science 6, no. 1 (2016): 88-117.

Hardjaloka, Loura. "Ketepatan HAKIM DALAM Penerapan Precautionary Principle Sebagai ‘Ius Cogen’ Dalam Kasus Gunung Mandalawangi” 5, no. 2 (2012): 134-53. https://doi.org/10.29123/jy.v5i2.132.

Hermawan, Sapto, and Wida Astuti. “Analysing Several ASEAN Countries' Policy for Combating Marine Plastic Litter." Environmental Law Review 23, no. 1 (2021): 9-22. https://doi.org/10.1177/1461452921991731.

. "Penggunaan Penta Helix Model Sebagai Upaya Integratif Memerangi Sampah Plasik Di Laut Indonesia." Bina Hukum Lingkungan 5, no. 2 (2021): 237-61. https://doi.org/10.24970/bhl.v5i2.164.

Imamulhadi. "Perkembangan Prinsip Strict Liability Dan Precautionary Dalam Penyelesaian Sengketa Lingkungan Hidup Di Pengadilan.” Mimbar Hukum

- Fakultas Hukum Universitas Gadjah Mada 25, no. 3 (2014): 416-32. https://doi.org/10.22146/jmh.16070.

Juanda, Sutiyanti. "Representasi Kerusakan Lingkungan Di Indonesia Dalam Puisi Media Daring Indonesia (Kajian Ekokritik)," 3, no. 2 (2016): 98-107.

M.W.A, Scheffer. The Precautionary and Preventions Principles, 1966.

Mahkamah Agung Republik Indonesia. "Surat Keputusan Mahkamah Agung RI 
No. 36/KMA/SK/II/2013 Tentang Pemberlakuan Pedoman Penanganan Perkara Lingkungan Hidup.," 2013.

Manan, Abdul. Penerapan Hukum Acara Perdata Di Lingkungan Pengadilan Agama. Jakarta: Kencana, 2008.

Mertokusumo, Sudikno. Hukum Acara Perdata. Yogyakarta: Liberty, 1993.

Mulyadi, Lilik. Kompilasi Hukum Pidana Dalam Prespektif Teoritis Dan Prakter Pradilan. Jakarta: Mandar Maju, 2007.

Parlina, Nurasati. "Penerapan Class Action Di Indonesia Studi Kasus Putusan Nomor 1794 K/ PDT/2004.” Jurnal Poros Hukum Padjadjaran 2, no. 2 (2021): 237-52. https://doi.org/10.23920/jphp.v2i2.377.

Pasal 1 angka 2 Undang-Undang Republik Indonesia Nomor 32 Tahun 2009 Tentang Perlindungan Dan Pengelolaan Lingkungan Hidup (2009).

Permana, Rizky Bayu, Dewo Baskoro, and Arie Afriansyah. "Hukum Internasional Made In Garut? Mengkritisi Status Jus Cogens Atas Prinsip Kehati-Hatian Dalam Mandalawangi." Bina Hukum Lingkungan 5, no. 1 (2020): 153-79. https://doi.org/10.24970/bhl.v5i1.156. (CC BY SA) license (https://creativecommons.org/licenses/by-sa/4.0/). 